\title{
"Fallen, Fallen is Babylon the Great"; :The Iraq War as "The Biggest Western Foreign Policy Disaster" as Reflected in Gregory Burke's The Black Watch
}

\author{
“Düşü, Düş̧ü Büyük Babil”: “Batı Dış Politikası'nın En Büyük Felaketi” \\ olarak Irak Savaşı: Gregory Burke'ün The Black Watch Adlı Oyunu
}

\begin{abstract}
İmren YELMIŞ⿻̧*
Abstract: The Iraq War which started in 2003 under the leadership of the U.S.A., the Bush administration, has entailed an irreparable loss, not only for Iraq as thousands of civilians died in the war, and chaos and disorder still prevail in the country, but also for the soldiers of the Scottish Black Watch regiment who, after they went to war, found themselves in "the Biggest Western Foreign Policy Disaster". This war, actually, began through a fiction formulated by the two contemporary Western imperialist countries, the U.S.A. and the U.K. which argued that Saddam Hussein had biological weapons in Iraq which would be used for terrorist activities. This fiction was enriched by some other myths or fabricated "truths", in which they argued that they would enter Iraq only in the name of "democracy," "civilising the barbarians" and "bringing human rights to them". Later, however, it was proven that this biological weapon story was nothing more than a fiction formulated by these two countries, and they used it to justify their invasion of Iraq, with the real reason for the war being the "oil" in Iraq, a reflection of the prevailing Western imperial ideologies. In this context, the Scottish playwright, Gregory Burke's challenging play, The Black Watch, might be considered a metaphor for the tragic consequences of the war. In line with this, this paper argues that Burke, in this play, uses the theatrical performance as an instrument of satire and a mirror reflecting the fact that Western imperialist ideologies continue in the $21^{\text {st }}$ century, causing enormous damage, Iraq War being most evident proof of this.
\end{abstract}

Keywords: The Iraq War, Oil, The Scottish Black Watch Regiment, Gregory Burke's The Black Watch

Öz: ABD ve Bush Yönetimi liderliğinde 2003 yılında başlayan Irak Savaşı, sadece binlerce sivilin savaşta öldüğü ve kaos ve istikrarsızlığın hakim olduğu Irak için değil, aynı zamanda, savaşa katıldıktan sonra, kendilerini "Batı dış politikasının en büyük felaketi” içerisinde bulan İskoç Black Watch Alayı için de çözümü mümkün olmayan kayıplara sebep olmuştur. Savaş, aslında, Saddam Hüseyin'in, terörist aktivitelerde kullanılmak üzere Irak’ta biyolojik silah bulundurmakta olduğunun kanıtlandığını savunan ve iki çağdaş emperyalist ülke olan ABD ve Birleşik Krallık tarafindan oluşturulan bir senaryo ile başladı. Bu senaryo, onların Irak'a sadece "demokrasi," "barbarları uygarlaştırma" ve "onlara insan haklarını getirme" adına gireceklerine dair bir "mit" veya sözde "gerçeklikle” zenginleştirildi. Ancak, daha sonra, bu "biyolojik silah hikâyesi"nin bir senaryodan ibaret olduğu ve bu iki ülkenin bunu sadece Irak istilasını meşrulaştırmak için kullandıkları ve bu savaşın gerçek sebebinin Irak’taki petrol olduğu kanıtlandı. Bu bağlamda, İskoç oyun yazarı Gregory Burke'ün Black Watch adlı iddialı oyunu, savaşın trajik sonuçlarının bir metaforu olarak düşünülebilir. Bu tartışmalar 1şığında, bu makale, Gregory Burke'ün bu oyun aracılığıyla, tiyatroyu, Batı emperyalist ideolojilerinin 21. yüzyılda halen büyük zararlarla devam ettiğini ve Irak Savaşı'nın bunun en açık kanıtlarından biri olduğunu gösteren bir ayna ve bu durumu eleştiren bir araç olarak kullandığını tartışmaktadır.

Anahtar sözcükler: Irak Savaşı, Petrol, İskoç Black Watch Alayı, Gregory Burke’ün The Black Watch Oyunu

\footnotetext{
** Dr., Hacettepe Üniversitesi, Edebiyat Fakülesi, İngiliz Dili ve Edebiyatı Bölümü, Ankara. imrenyelmis@gmail.com

* Revelation 14,8; The Holy Bible. Michigan 1984.
} 
The historic location of Babylon has throughout history been a topic for literary works, but its representation in the Scottish playwright Gregory Burke's The Black Watch might be argued to be one of the most challenging ones, as it seriously addresses Babylon, the place, in terms of the ongoing Western imperialism of the $21^{\text {st }}$ century. The play, whose director was John Tiffany, and which was first performed at the Edinburgh festival on the $5^{\text {th }}$ of August 2006 by the National Theatre of Scotland (NTS) (Pattie 2011, 31), is based upon the Iraq War which started in 2003 under the leadership of the USA, and with the military support of the UK. The Black Watch whose characters represent the soldiers of the Scottish Black Watch Regiment is the projection of this tragic process and consequences of the war from the point of view of the soldiers of the Black Watch regiment. Actually, the regiment had an active role in this war. When they find themselves in "the biggest western foreign policy disaster" (Burke 2010, 71), however, they gradually understand the reality that they were, in fact, nothing more than a disaster to Iraq, and they were only playing the roles that were given to them by the UK government which sends the regiment into "the Triangle of Death" (Burke 2010, 8), the most dangerous place in the Iraq War. So, as a part of imperial ideologies, the Black Watch was used by the UK government as was concisely explained by the Sergeant: "You're here because Her Majesty's Government has decided that there's no way we can sit down in Basra topping up our tans when our allies are getting ten types ay shite knocked out ay them by the mujahidin. [...] It's our turn tay be in the shite" (Burke 2010, 17).

Gregory Burke explains in the introductory part of The Black Watch that "soldiers are still dying for unclear, military objectives. We are still occupying other countries and, as a character in the play most eloquently puts it, 'f***ing their day up"' (Burke 2010, vii). The roles played by the Black Watch soldiers as a consequence of the USA's neo-colonial, capitalist, globalised and western imperial ideologies, on the one hand, were re-constructing the Western Self and helping the USA guarantee its place as the sole world power, and, helping the UK return to its former "glorious" imperial ideologies, while, on the other hand, were deconstructing the Black Watch self. In this article, Gregory Burke's The Black Watch will be discussed as a play that satirises Western imperial ideologies embodied in the tragic Iraq War in line with a further argument about what Babylon, an ancient city in Mesopotamia, means for the USA, and for Scotland and the UK which had an active role in the formation of the USA's disastrous neo-colonial discourse. Actually, Babylon maybe regarded as a key symbol of the greed and selfishness of Western imperialism, for their own political and economic benefits, a signifier employed to question the war which, as is underlined by many critics, was fought for control over oil supply, rather than for "democracy" as was claimed by the Bush and Blair governments. Hence, Babylon might be considered as a symbol for the chaos between Eastern and Western civilisations (Orient and Occident), an instrument to reflect the condition of the Black Watch in the $21^{\text {st }}$ century, and a space of power and politics, as well as a "theatrical" space upon which the Black Watch soldiers play the roles determined for them. In order to clarify these points, firstly, the historical background of the war in line with the roles that the USA and UK governments played in the war as a part of their imperial ideologies and the function of the Scottish Black Watch within this war will be given. Then, secondly, the play, employing these arguments, is further discussed as a satire of the Iraq War, a war which took place as a consequence of these ideologies.

\section{Western Imperial Ideologies: the USA, the UK and the Myth of "Civilising Mission"}

It is true that, in political terms, colonialism is over; however, the "postcolonial age" brings many questions, such as, "do we really live in a post-colonial era in the $21^{\text {st }}$ century in which 
the traces of colonialism are still so clear?," "Isn't it possible to see that even in this era the western imperialist countries still exploit the resources of many countries by trying to camouflage their imperial ideologies through some political myths?". In the contemporary world, imperial ideologies are still based upon power relations. When the constant historical evolution of imperialism is carefully analysed, British imperialism dominant in the $19^{\text {th }}$ century can clearly be observed to be replaced at the beginning of the $20^{\text {th }}$ century by American imperialism, a constant from the mid- $20^{\text {th }}$ century, to the present day. Although both countries represent Western imperial countries, unlike the presence of formal colonies under British imperialism, in American imperialism, it is possible to talk about a kind of imperialism which "can function without formal colonies," and the USA, might be considered as being "the imperial country," which, in Ania Loomba's words, "is the 'metropole' from which power flows" (2000, 7). She aptly further argues that

It is perhaps premature to proclaim the demise of colonialism. A country may be both postcolonial (in the sense of being independent) and neocolonial (in the sense of remaining economically and/or culturally dependent) at the same time. [...]. The global order does not depend upon direct rule. However, it does allow the economic, cultural, and (to varying degrees) political penetration of some countries by others. (Loomba 2000, 7).

Actually, Iraq is one of the American neo-colonies highlighted by Loomba, as it is not a formal colony but still is controlled by a foreign ruler, the USA, economically and politically, which was the tragic outcome of the invasion of Iraq followed by the Iraq War. Considered in relation to the contemporary situation of Iraq, the neo-colonial relationship between the USA and Iraq might be understood in a better way. In this context, the year 2011 might be a key time for this relationship, as no sooner had the "invasion end[ed]," than "neo-colonial rule [began]" (Cantalucci 2011) in Iraq, as this means that the USA would control the country not only politically but also economically. This economic control might also be considered as a token of Iraq's subjection to the USA's imperial and neo-colonial discourse. As can clearly be observed, the current notion of imperialism is quite different from that observed in the $19^{\text {th }}$ century, from the one generally centred upon formal colonies. The USA, as one of the imperial powers in the contemporary contest of power relations, in a way, uses Iraq to participate in this war of global hegemony, as is also explained by Foster, Yates, Magdoff and Sweezy in their article entitled "U.S. Imperial Ambitions and Iraq" before the Iraq War even started, but when it was only being discussed by the USA: The USA's "goal" in the invasion of Iraq "would be nothing less than the visible global projection of U.S. power through the assertion of American dominance over the entire Middle East. What the world is now facing therefore is the prospect of a major new development in the history of imperialism" (2002). Then, what these editors were discussing in their article became reality in 2003, as the USA really invaded Iraq in consequence of the American neo-colonial and imperial ideologies.

The proximity of ideology and myth-making cannot, in fact be denied. As a part of its foreign policy based upon its desire for global hegemonic power, the USA has formulated a discursive construction in which Iraq is seen as a tool for its imperial ideologies. In order to justify the Iraq war, a "truth" or "myth" whose hero was George W. Bush was formulated by "fictional accounts for the reality of war" (Hoskins and O'Loughlin 2010, 68). This myth was put into words by Colin Powell, the U.S. Secretary of State, who stated in his speech to UN General Assembly in 2003 that "[t]here can be no doubt that Saddam Hussein has biological 
weapons and the capability to rapidly produce more, many more. And he has the ability to dispense these lethal poisons and diseases in ways that can cause massive death and destruction" (as cited in Iyengar and McGrady 2007, 99). This myth, unfortunately, was made more powerful by one of the most significant and non-innocent tools of ideological state apparatuses, media tools, in Entman's words, 'media framing [...] [like] the 'war on terror,' a particular media frame that has been very successfully used by the Bush administration as a justification for increased security measures for the U.S. as well as the invasion of Iraq" (Oates 2008, 24). Through the media, a tool for the USA to exercise its power, the Bush administration found the opportunity of disseminating their so-called humanitarian mission to save the world from the dangers of these biological weapons to the globe. This shows that, in a way, they were in search of justification for their invasion, control and subjection of Iraq, the paradise of oil. Hence, in the formulation of the "truth," they tried to associate the invasion of Iraq with "progress." Hoskins and O'Loughlin, in a way, summarise this "myth of progress" as follows:

This was 'The Battle for Global Values,' according to Tony Blair (2007), between civilisation and its enemies. As the US and its allies claimed to make 'progress' in Afghanistan and Iraq, such a claim positions any actors resisting this progress as being against progress per se. [...]. Hence, the war on terror represents a stretching out into an empty temporal space ahead, to be filled in by a US-led progress synonymous with the progress of humanity per se. Such progress might include, we could infer, the enforcement of universal human rights (or, the universal enforcement of human rights) and perhaps even the achievement of 'freedom,' however defined. The barbarians lie somehow outside this time and space. It is as though they hate our gods and customs, and their gods and customs belong to a different cosmos entirely (2010, 174-75).

As in colonial discourse, in neo-colonialism too, the line between binary oppositions like "us" and "them" and the constructed image of the non-Western 'Other' are reinforced. "Them" is still identified and associated with anarchy, and neo-colonialism has reiterated stereotypical views regarding the "barbarism of the primitive", the "inferior" and "savage". Democracy and the "civilising mission", in this sense, become tools for Western imperialists in preserving their discursive codes and orders through which they try to legitimise violence, which may be considered as being the "democratisation of violence" (Cottle 2006, 144). To have a better view of this idea of democratisation, it might prove useful to state the American discourse that is underlined by Hoskins and O'Loughlin: "the discourse of US exceptionalism - that the US is a chosen nation, the city on the hill, last best hope of mankind - or the discourse of victimhood among Arab or Muslim peoples, that, following colonial empires, oppression by the West continues through neo-colonial projects (wars in Iraq and Afghanistan)" (2010, 167). Hoskins and O'Loughlin also question how such a constructed myth can be so very influential in the justification and legitimization of the invasion of a country, and a war, the Iraq War, in the socalled post-colonial era: "We must therefore ask how these differing speeds and tempos contribute to the dynamics of control and chaos, order and disorder, and how this feeds into the legitimization of war" (2010, 167). The USA's constructed political fiction shows us how sometimes myths might determine and shape a country's political and economic situation. By means of these myths, the American administration has tried to sustain their hegemony in the world and justify their violence and the conflicts that they have created in those places which are claimed to be indulging in terror. In this sense, it might be argued that Washington, actually, "had used the inspection process as a Trojan horse in its attempts to destroy the Iraqi regime" 
(Foster, Yates, Magdoff and Sweezy 2002) as an instrument for its imperial designs. In other words, the investigation of "Iraq's [actually] non-existent WMD capability in 2003" (Hammond 2007,59 ) was only a tool of American imperialism employed to justify the invasion of Iraq in the name of the so-called "democracy" which would totally transform the claimed dictatorship observed under the Saddam Hussein regime. As Michael Ignatieff whose following words appeared in the New York Times Magazine on the $28^{\text {th }}$ of July 2002 claimed, “America's entire war on terror is an exercise in imperialism. This may come as a shock to Americans, who don't like to think of their country as an empire. But what else can you call America's legions of soldiers, spooks and special forces straddling the globe?" (as cited in Harvey 2003, 3).

In fact, the American myth later collapsed as it was subsequently proven that all of the claims and "realities" of the Bush administration were nothing more than fabricated evidence and constructed self-serving tools employed by this administration. As Iyengar and McGrady note,

[t]he successful invasion of Iraq and overthrow of the Hussein regime was followed by several months of frenzied American efforts to find the Iraqi weapons of mass destruction. Gradually, it became apparent that the weapons did not exist. As for the second alleged threat posed by Iraq - the close relationship with Al Qaeda - the 9/11 Commission and other experts ultimately concluded that, although there were isolated contacts, these did not amount to a 'collaborative relationship'. Thus both key premises of the policy of unilateral intervention proved erroneous (2007, 85-86).

Furthermore, as Jay Bookman argued in 2002 in his "The President's Real Goal in Iraq,"

[t] he official story on Iraq has never made sense....It [the threatened invasion of Iraq] is not about weapons of mass destruction, or terrorism, or Saddam, or UN resolutions. This war, should it come, is intended to mark the official emergence of the United States as a full-fledged global empire, seizing sole responsibility and authority as planetary policeman. It would be the culmination of a plan 10 years or more in the making, carried out by those who believe that the United States must seize the opportunity for global domination, even if it means becoming the 'American imperialists' that our enemies always claimed we were....Rome did not stoop to containment; it conquered. And so should we (as cited in Foster, Yates, Magdoff and Sweezy 2002).

The intervention, as can be seen, was never innocent; neither was it made due to the fear of the threat that would be experienced in consequence of the so-called terror to come from Iraq. The USA stated this intervention was made under the name of a "civilising mission" and for "human rights". Their murder of many civilians, however, has nothing to do with so-called human rights. The entire war, hence, was a war crime marked by atrocities.

And allusion is made by Gregory Burke in The Black Watch, to the civilians who were killed in this war by the American soldiers. In this play there are no American soldier characters; however, they are always mentioned negatively: either while "bullying" the Middle East through the invasion of Iraq or while killing civilians, as can be understood in the following conversation, which also reflects the USA's position in Iraq, and how they became a disaster for many innocent people in consequence of this "erroneous" story: 
Writer: Did you see much of the Americans?

Rossco: No really. You tend tay keep out ay their way.

Cammy: There was one time we watched them bombing $\mathrm{f}^{* * *}$ out of this village.

Macca: For four $\mathrm{f}^{* * *}$ ing hours.

Nabsy: There was nay cunt there.

Cammy: Nay insurgents, anyway.

Stewarty: When we got back tay camp ay, I went and asked a couple ay cunts, what was going on there, last night.

Nabsy: We watched them bombing the shite out ay the gaff for $\mathrm{f}^{* * *}$ ing ages.

Macca: It was $\mathrm{f}^{* * *}$ ing mental.

Stewarty: They were like, aye, there was nay cunt there, they killed two civilians.

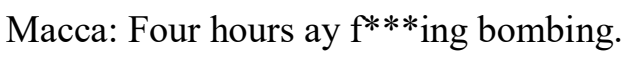

Cammy: Arseholes.

Rossco: I mean, it's no like the Iraqis could've fought against us anyway ay.

Granty: The difference in the firepower and the kit, it's that much (Burke 2010, 47-48)

(emphasis mine).

This conversation is actually about the civilian deaths caused by the U.S.'s and its allies' invasion of Iraq. The exact number of those who died in the war is unknown, but, according to the data stated on the website of the Watson Institute, International and Public Affairs, Brown University, it is estimated that between 2003, when the USA and its allies invaded Iraq, and 2015 , nearly 165,000 civilians died as a result of the violence brought by the war "through aerial bombing, shelling, gunshots, suicide attacks, and fires started by bombing" ("Iraqi Civilians", 2015). However, it is estimated that the number is more than the official figures. According to an academic research conducted by researchers from the USA, Canada and Iraq, "[a]bout half a million people died in Iraq as a result of war-related causes between the US-led invasion of 2003 and mid-2011" and "more than 60\% of the estimated 461,000 excess deaths were directly attributable to violence, with the rest associated with the destruction of infrastructure and from other indirect causes. These include the failures of health, sanitation, transportation, communication and other service systems ("Iraq Study Estimates", 2013). As can clearly be observed, this so-called "civilising mission" caused the death of many civilians, civilians who were not directly involved in the war.

If Babylon means the guarantee of sustaining the American hegemonic power for the USA, for the UK it actually means the dream and desire to regain the lost global hegemony. Before the Second World War, the UK was an empire and the world power and that World War II changed power relations and global hegemony. The title of "world power" which once belonged to the UK passed to the USA as emphasised by David Harvey. He points out that after the British "Empire is kaput" there were "sudden belligerent claims, most notably represented by the front cover of the New York Times Magazine for 5 January 2003: 'American Empire: Get Used to It.' For me, it feels passing strange to come to consciousness of the world at the moment of one empire's passing and to come to retirement age at a moment of such public proclamations of the official birth of another" $(2003,3)$. The UK, however, never lost its imperial ideologies even in the $21^{\text {st }}$ century, and British foreign policy was shaped by these ideas. With this imperial ideology in mind, the UK administration under the leadership of Tony Blair saw the war in Iraq and collaboration with the USA as a great opportunity for the UK to 
regain its imperial power through this "civilising mission". As Krieger explains,

[t]he war in Iraq is the outgrowth of legacies left in the mindsets of contemporary Labour leaders by the world-views of their predecessors, as these mindsets have been shaped by the legacies of empire, [just as the USA] understood as a civilising mission expressed both in support for humanitarian intervention and in support for a robust international role to advance UK interests and influence, both of which may involve the use of force $(2013,599)$.

Krieger also clearly explains how the Iraq War was used as a means to fulfil this imperial desire:

The end of empire did not bring the end of great power aspirations, but it did bring new British foreign policy formulations and challenges. [...]. There was [...] a profound drawback to the special relationship with the United States. [...]. This context of post-imperial aspirations and the problem of reconciling the US-UK special relationship with the threering vision of Britain's place in the world help explain Britain's continuing global role, leading up to, and including, the war in Iraq.

Tony Blair's role in the Iraq story has to be understood by looking outwards to the pulling force of Washington, and to the quite reasonable judgement that British interests are often served by powerful strategic ties to the United States as the hegemonic power. That said, Blair's decision to join the war in Iraq, despite the readily foreseeable political costs, can be understood at least as well by looking inward, to the premises of past and present British - and, in particular, Labour foreign policy orientations. These orientations present a complex and ambivalent portrait of a party with powerful, and still unresolved, crosscurrents of imperial and anti-imperialist orientations $(2013,598)$.

Tony Blair, for the sake of gaining imperial hegemony in the world, acted together with the Bush administration, and like the American administration, tried to justify the Iraq War using the media as a tool to serve his ends. Blair made a self-serving deal behind closed doors with Bush, and, like Bush, claimed that this war was to prevent terror in order to justify the war. As Oates states, "Prime Minister Tony Blair's administration became famous over a report by a $B B C$ freelance correspondent that the Labour government had 'sexed up' the evidence of weapons of mass destruction in Iraq in order to build public consensus for sending British troops to war. [However] it later became apparent that evidence of these weapons was inconclusive" $(2008,38)$. The war, and particularly the revelation of the fabricated myth of the existence of the biological weapons, actually, projected the selfishness of and the imperial agreement between the USA and the UK, and the desire of these two Western countries to have a say and establish hegemony in the Middle East.

Gregory Burke, to emphasise that throughout history this Western imperial desire has remained the same, in The Black Watch reflects these issues by means of underlining the sentence told by the Writer, the character carrying out an interview with the soldiers of the Black Watch: "history is important" (Burke 2010, 25), and of symbolic references to the imperial history of Britain in the Middle East through an army officer, Thomas Edward Lawrence (1888-1935), known as Lawrence of Arabia and his famous book entitled, Seven 
Pillars of Wisdom, A Triumph. Before discussing how Lawrence and his book are discussed in The Black Watch, and to clarify the on-going Middle East project of the Western imperialism, it seems useful to provide a concise account of Lawrence's significance in the Middle East during the First World War. Britain, in fact, signed a secret agreement called the Sykes-Picot Agreement with France in 1916 to share the Middle East between the two countries. The British government did its best to create an Arab Revolt in the Middle East to be able to establish its hegemony over the region. As Anderson, in his "The True Story of Lawrence of Arabia" explains,

the British government had made [promises] to Hussein [under whose leadership the Sharifian Hashemite Revolt began in the area] in order to raise the Arab Revolt: full independence for virtually the entire Arab world. [...] [J] ust months after cementing that deal with Hussein, Britain had entered into a secret compact with its chief ally in the war, France. Under the Sykes-Picot Agreement, the future independent Arab nation was to be relegated to the wastelands of Arabia, while all the regions of value - Iraq, greater Syria - were to be allocated to the imperial spheres of Britain and France (2014).

To be successful in this project, they employed T. E. Lawrence, who had a real ability for propaganda, as an agent. Lawrence was working in the Middle East in the name of the British forces; leading the Arabs against the Ottomans. He played an active role in the Arab Revolt, the key event in the formation of the contemporary Middle East, which has still not been freed from the fragmentation, chaos and disorder brought about by this event. Field Marshall E. H. H. Allenby saw Lawrence as so successful in the demolitions in the area and in the course of the revolt that, when Allenby retired, he praised Lawrence as "the mainstream of the Arab movement'. [...] 'Lawrence was under my command, but, after acquainting my strategic plan with him, I gave him a free hand. His cooperation was marked by the utmost loyalty, and I never had anything but praise for his work, which, indeed was invaluable throughout the campaign" (Faulkner 2016, n. p.). As a consequence of the efforts of Lawrence, and due to the fact that "there was the issue of European competition in the Orient" (Said 1979, 248), soon, "[t] he signs of Oriental claims for political independence were everywhere; certainly in the dismembered Ottoman Empire they were encouraged by the Allies and, as is perfectly evident in the whole Arab Revolt and its aftermath, quickly became problematic" (Said 1979, 248), as a result of which the Middle East was divided among Western imperial countries. Moreover, Emir Faisal, who "was the personification of a form of Arab nationalism distorted by Hashemite ambition and its dependence on British imperialism" (Faulkner 2016, n. p.), and who played a leading role in the Arab Revolt against the Turks, acted together with Lawrence during the First World War. As Anderson points out,

[a]cting as Faisal's personal agent, [Lawrence] frantically lobbied prime ministers and presidents to uphold the promises made to the Arabs and to prevent a peace imposed along the lines laid out in Sykes-Picot. By that scheme, 'Greater' Syria was to be divided into four political entities - Palestine, Transjordan, Lebanon and Syria - with the British taking the first two, the French the latter. As for Iraq, Britain had planned to annex only the oil-rich southern section, but with more oil discovered in the north, they now wanted the whole thing (2014).

Western imperial countries divided and ruled the Middle East for their own benefit, and "[t]he 
British agent-Orientalist [Lawrence] [...] [who] took over both the role of expert-adventurereccentric [...] and the role of colonial authority" (Said 1979, 246), was a part in these aims and plans. All these efforts of the UK in the 1910's actually reflect the traces of British imperialism and its consequences that still remain today. Furthermore, Lawrence, known in the Middle East as "an expert in demolitions" (Anderson 2014), "contributed" to this process not only through his propaganda and efforts triggering Arab nationalism. He was also an active participant in the fragmentation and demolition process in the area, the leader of "British demolishing teams, working with their Arab rebel allies" (Anderson 2014) who demolished the railways, particularly the Hejaz Railway, its bridges, track and telegraph constructed by the Ottoman State through planting mines (Faulkner 2016, n. p.).

The English, through Lawrence, in fact, brought nothing more than disorder and instability to the Middle East during the First World War. What the USA, the UK and the Black Watch soldiers mentioned in The Black Watch are doing in Iraq, is no different from the things that Lawrence did a century ago. In the Iraq War, the mission of British imperialism under the agency of T. E. Lawrence in the $20^{\text {th }}$ century is, in a way, adopted by American neocolonialism, assisted in the $21^{\text {st }}$ century by the UK military in which is included the Scottish Black Watch regiment. The fact that Cammy and Fraz talk about Lawrence and his book The Seven Pillars of Wisdom is therefore no coincidence in this context:

Cammy: He was here, you know?

Fraz: Lawrence ay Arabia?

$[\ldots]$

And what did he do, when he was here?

Cammy: What did he do?

Fraz: Aye. Aye. What's it about?

Cammy: It's ... eh, well, he kinday ...

Fraz: You dinnay ken what it's about?

Cammy: I ken it's The Seven Pillars ay Wisdom, but it's hard tay tell what it's about when there's only half ay it ay.

Fraz: It's the Three and a Half Pillars ay Wisdom?

Cammy: That's the trouble way paperbacks ay. They are nay designed tay stand up tay the rigorous ay expeditionary soldiering.

Fraz: D'you ken who's got the other half?

Cammy: Some'dy in Five Platoon, I think he said.

Fraz: You gonnay get it off him?

Cammy: $\mathrm{F}^{* * *}$ aye. (Pause.) Where are Five, anyway?

Fraz: $\mathrm{F}^{* * *}$ knows. Driving about somewhere trying tay find the cunts that are mortaring us.

Cammy: Have we still not found them?

There is an explosion in the distance.

Fraz: Apparently not.

Cammy: Well, I hope they're back soon - (Holds up the book.) because now I ken how it finishes I'm dying tay ken what the $\mathrm{f}^{* * *}$ the cunt was daying here in the first place. (Burke 2010, 13-14). 
Gregory Burke, in this play, in this way, shows that the imperialist Western authority and project over the "Orient" and the actions and consequences of British imperial history have not disappeared. On the contrary, they continue with great damage in the Middle East. Burke, in this way, uses theatre as a key metaphor with which to rethink the East-West dichotomy, Western imperialism, politics, power relations and war, and the image of the "superior civilisation" (Said 1979, 249) of the West. That Cammy has read only half of the book and that he says that the "Three and a Half Pillars ay Wisdom" has been given to somebody in Five Platoon might signify the idea that The Black Watch or Western countries like the UK and the USA have started where Lawrence had left off, and that they are continuing Lawrence's imperial mission once again given to them by the U.K. administration. All this shows, in McLeod's terms, "the continuing agency of colonial discourses and relations of power in the contemporary world" (McLeod 2012, 279), which is reflected through the words, "old-fashioned bullying" (Burke $2010,41)$ in the play.

In fact, due to its oil riches, the Middle East has been an area in which Western imperialists have fought or at least tried to find a way of reconciliation to have a say in the area. Harvey talks about how contemporary global capitalism is functioning at present. He puts forth the idea that "[t]here is $[\ldots]$ an even grander perspective from which to understand the oil question. It can be captured in the following proposition: whoever controls the Middle East controls the global oil spigot and whoever controls the global oil spigot can control the global economy, at least for the near future" $(2003,1.19)$. He further states that "[w]e should not, therefore, think solely of Iraq, but consider the geopolitical condition and significance of the Middle East as a whole in relation to global capitalism" $(2003,19)$. That the war was for the control of oil, was, in fact, denied by both USA and UK leaders; however, it was talked about on many occasions by many journalists, one of the most outstanding and controversial being Rupert Murdoch, a media proprietor. About this issue, Roy Greenslade argues that

[m] ost revealing of all was Murdoch's reference to the rationale for going to war, blatantly using the o-word. Politicians in the United States and Britain have strenuously denied the significance of oil, but Murdoch wasn't so reticent. He believes that deposing the Iraqi leader would lead to cheaper oil. 'The greatest thing to come out of this for the world economy...would be $\$ 20$ a barrel for oil. That's bigger than any tax cut in any country (2003).

In fact, the wish of the USA to have a say in the Middle East, associated with its oil reserves has been significant for American geopolitical decisions particularly since the Second World War. Since then, American geopolitical discourse in the region has gradually been replacing the English one. In particular, the 1950's was of paramount significance in this context, as beginning from this decade, the impact of the newly emerging world empire of the U.S.A. began to be felt in the region. In this respect, as argued by the Editors in the Monthly Review,

[c]rucial to the whole conception of the Grand Area was control of the Middle East, which was regarded as part of the old British Empire, and absolutely essential for the economic, military, and political control of the globe-not least of all because it was the repository of most of the world's proven oil reserves. The United States thus began a long series of overt and covert interventions in the region in the 1950's, the foremost of which was the 1953 overthrow of the democratically elected Mossadegh government in Iran, which had nationalized foreign-owned 
oil companies. The success of the U.S. drive was clear. Between 1940 and 1967, U.S. companies increased their control of Middle Eastern oil reserves from 10 percent to close to 60 percent while reserves under British control decreased from 72 percent in 1940 to 30 percent in 1967 ("U.S. Imperial Ambitions and Iraq").

Due to this desire, the Iraqis were denied any kind of individuality or human rights, but, were dehumanised and seen as nothing more than an object/a thing, and the country was seen only as a door to the riches of Babylon and as a matter of economic practice.

Gregory Burke, in a way, formulates proximity between this economic practice and sexuality in The Black Watch. This analogy reminds of the metaphorical link between the female body and a land which is always thought of as female in colonial and postcolonial literature, which has also been argued by Ania Loomba, who states that "sexual and colonial relationships become analogues to each other" $(2000,73)$. A male "is the active discoverer of the female body, and desires to explore it in the same way as the European 'adventurer' who penetrates and takes possession of lands which are seen as passive, or awaiting discovery. Here, the sexual promise of the woman's body indicates the wealth promised by the colonies" (Loomba 2000, 73). Iraq whose hidden treasure is oil, accordingly, represents the informal (female) colony to be exploited by the masculine body in The Black Watch. In the play, "everyone [...] has porn all over their wagons" (Burke 2010,37), and they watch pornography, and, by doing so, in the Sergeant's words, they "commit deviant sexual acts" (Burke 2010, 34). By means of this signification, Iraq is implicitly sexualised, and metaphorically raped, and a parallel is drawn between pornography and oil in the play:

Fraz: What a shame. I mean, what on earth is wrong with a healthy young woman taking a little bit of pride in her appearance, eh, Sergeant Munroe?

Sergeant: Nothing, sir.

Officer: Absolutely $\mathrm{f}^{* * * i n g}$ nothing, eh boys?

Fraz: What about the cars, sir?

Sergeant: The cars are fine.

Fraz: Well, they're kinday Granty's porn ay? And we would nay want the Muslim world thinking we were here tay steal their petrol for our lovely cars.

Sergeant: Good thinking. Take them down then.

Officer. No.

Sergeant: Leave them up.

Officer: Leave it all up.

Sergeant: Sir?

Officer: It's important that we have a reminder of what we're here fighting for. Porn and petrol. That's a joke by the way, Fraser.

Fraz: Yes, sir.

Officer: As you were, chaps.

The officer exits (Burke 2010, 35-36).

This scene is significant not only because it reflects Burke's sarcastic tone in the "joke" part, but also because it represents the above mentioned relationship between the female body and the colonised (female) land, and the metaphor of male control over a feminised country. The 
soldiers, albeit not physically, try to satisfy their sexual desires by means of a virtual reality, and seek their sexual "adventure" through pornography, which is similar to the "adventurer" "who penetrates and takes possession of lands which are seen as passive, or awaiting discovery" (Loomba 2000, 73). The paradise offered by pleasure-centred sexuality is a signifier of colonial desire, alludes to the Western (including the Scottish Black Watch) exploitation of Iraq for the sake of the wealth of the land, that is, oil, and might also signify the never-ending thirst for the riches of the colonised country albeit not formally. The Sergeant's following words, by the same token, are significant: "Get that porn down. You dinnay want the Muslim world turning intay the BBC tay see a lead ay porn," and "Do not commit deviant sexual acts in front ay embedded journalists" (Burke 2010, 34). These sentences not only show literally the idea that the imperialist-minded people directly indulged in the Iraq War do not want to feel degraded in the Muslim world by openly showing their real aim, but also can be considered as a sarcastic approach to how the media is shaped according to the commands and formulation of those who have a say in certain matters, and how the media hides or changes the facts according to the wishes of such people.

\section{Iraq War as "the biggest western foreign policy disaster"}

Before discussing The Black Watch in relation to the great impact of the Iraq War upon the Black Watch soldiers, it seems useful to provide some brief historical information concerning this regiment to have a clear idea about its function in the war. The Black Watch, before its service in the British Army, was an independent army, serving only Scotland as is also explained by Cammy in the play: "We started before Culloden. We dinnay really ken [know] when. 1715, or maybe 1725. When Scotland was an independent nation we were [...] mercenaries tay half ay [...] Europe. But it was 1739 when we really threw our lotin way the British" (Burke 2010, 30). In 1739, nothing was the same since as at this time the Scottish army began to act with the English. About this issue Zerdy notes as follows:

The former Black Watch (Am Freiceadan Dubh) played a significant role in dozens of domestic and foreign military campaigns. Primarily comprising men from Dundee, Perthshire, Angus and Fife, the battalion began its work in the Highlands where it kept watch over clans to prevent smuggling and thieving. After 1739 the regiment bolstered military campaigns across the British Isles and farther afield. The British government deployed the men to sites as diverse as the West Indies, Crimea, India, Northern Ireland, Cyprus and the American colonies to establish and sustain the expanding reach of the British government during and following its imperial reign. In 2003, Black Watch soldiers found themselves in Iraq, supporting the US-led invasion of the country $(2013,181)$.

As can clearly be understood, the Black Watch has been involved in imperialist projects for a long time, and the Iraq War was not their first experience of imperial history. Hence, it can be argued Davidson might be right in being against the idea that "Scotland [had] been subject to English imperialism" $(2000,90)$ in history. He does not agree with D. McCrone, T. M. Devine and R. J. Finlay (eds) who argued that Scotland was "a successful junior partner in the wider process of British imperial colonialism" (Davidson 2000, 106). He, on the contrary, claims that Scotland had given decisions on fighting for imperial matters on its own. In other words, according to Davidson, Scotland, throughout history, has taken active role in western imperial ideologies as is also admitted by the Sergeant in The Black Watch: "It's our turn tay be in the 
shite. But we've had three hundred years ay being in the shite" $(2000,17)$, meaning western imperial history. Moreover, as Robinson states, "[t]he regiment had come into being as an agent of the British Crown and government and had thus acted as a military symbol of the historical alliance between England and Scotland" $(2012,398)$.

Actually, the Black Watch in The Black Watch, is represented as a regiment which, at first felt proud to be involved in the Iraq War, which was shown as Western civilisation's effort and "mission" to "liberate" Iraq from Saddam Hussein, because it would be a heroic deed to accomplish, like the many wars their ancestors had previously participated in. They joined the army when they were young. Many characters in the play had had family members who had served in the regiment: Cammy's father "was in it, years ago" and grandfather who fought "at Tobruk, years and years ago" and a great-grandfather who was in the regiment "years and years and years ago" (Burke 2010, 24-25), and Granty "had a cousin in the Paras" (Burke 2010, 25). So, as the Writer says, "history is important" which is approved of by Granty, too, who says, "They drum it intay you fay the first day" (Burke 2010, 25), and Cammy who accentuates the significance of history for the regiment: "That's what a regiment is ay? It's history. The Golden Thread. That's what the old timers go on about. It's what connects the past, the present and the future..." (Burke 2010, 25). In order to emphasise the significance of heroic deeds and history for the Black Watch, Burke brings forth some historical details as expressed by Lord Elgin:

Lord Elgin enters with a sword. He places the sword on their table and addresses them [the Black Watch soldiers].

Lord Elgin: Now as you know, my ancestor led his men at Bannockburn and is buried nearby at Dunfermline Abbey. He led his men in a fight for freedom from the tyranny of a foreign power and the need then, as now, for Scotsmen to serve their country in its hour of need is as great. [...] Here on this table in front of me is the sword of my ancestor. The twohanded claymore carried by him on that fateful day six hundred years ago (Picks up the sword). The sword of Robert the Bruce. [...] I say to you now, as he asked his men that day at Bannockburn, I raise the sword of King Robert the Bruce of Scotland high above my head - (He does) and ask you - (Shouts) wha'll follow a Bruce? (Burke 2010, 25-26).

The sword of Robert the Bruce whose "struggles for independence were adopted as one of the central chapters in a story of Scotland based upon struggle" (Pittock 1991, 27) symbolises his historic deeds throughout the efforts to gain independence for Scotland against England and his success and heroism in doing this at the Battle of Bannockburn in 1314, all of which are used to call the Black Watch soldiers to the Iraq War. The sword, as a historical and cultural icon, is in this respect, nothing more than an ideological state apparatus used to inject historical pride and national feeling into the soldiers. To be a representative of this national pride and being promised many attractive offers by Lord Elgin, these ideologically manipulated soldiers who are filled with youthful heroic ideals volunteer for the Iraq War:

Granty: How much?

Lord Elgin: What?

Granty: How much?

Lord Elgin: How much?

$[\ldots]$

Rossco: Aye. 
Lord Elgin: This is Robert the Bruce's sword.

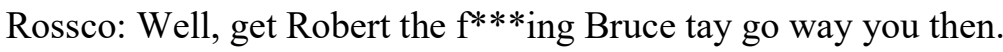

Cammy: Aye.

Lord Elgin: Bannockburn. [...]. Freedom. [...]. Robert the Bruce and that?

Granty: We're still wanting f***ing paid.

Lord Elgin: Paid? [...] $\mathrm{F}^{* * *}$ ing paid? [...] Our country faces the gravest peril, the Hun threatens our very civilisation. [...] D'you think you'll be getting $\mathrm{f}^{* * *}$ ing paid when the Kaiser bowls up the road and takes over? [...] I mean, come on, it's no just the money. There's the travel. [...] Well, France anyway. [...] The fresh air, the meadows, the rivers. The Somme region's $\mathrm{f}^{* * *}$ ing beautiful this time ay year ... You'll no be crouching in an eighteen-inch seam over there. [...] What more do you want? Three square meals a day, games of football way your mates, guns...

Rossco: We get guns?

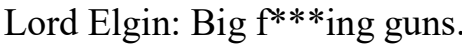

Rossco: Guns are $\mathrm{f}^{* * * \text { ing magic. }}$

Lord Elgin: Guns and football and drink and exotic poontang and that. [...] Shoot a few

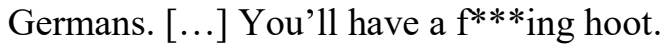

Cammy: What about glory?

Lord Elgin: Glory?

Cammy: Aye?

Lord Elgin: Oh aye ... aye ... the glory. [...] The glory of returning, at Christmas, a hero. [...] Did I mention it would be all over by Christmas?

Cammy: Oh well, when you put it like that.

Granty: Aye.

$[\ldots]$

Granty: I definitely fancy it.

$[\ldots]$

All: Where do we sign? (Burke 2010, 25-29).

This scene, in which, in a way, glory is sold to the soldiers, is important in neatly summarising the historical and national background of the Scottish nation in a few sentences and it reflects the significance of fighting for one's own country till they come to the point of fighting in Babylon. This scene is also sarcastic in that it implies that the soldiers, in the Iraq War, do not fight for the independence or protection of their own country with any kind of national feeling or patriotism, unlike the war fought by Robert the Bruce; they even did not know what are the reasons for fighting in the "Ancient home ay Babylon" the "Birthplace ay civilisation" (Burke $2010,10)$. As is also expressed by the Black Watch soldiers in the play, they participate in the war only for personal reasons. They confess that they joined the army "No for our government" (Cammy), "No for Britain" (Macca), "No even for Scotland" (Nabsy) (Burke 2010, 72), but for "my regiment" (Cammy), "for my company" (Rossco), "for my platoon" (Granty), "for my section" (Nabsy), "for my mates" (Stewarty) (Burke 2010, 72). Moreover, in the same scene where Lord Elgin talks about the glories of Robert the Bruce, the soldiers totally ignore them and ask instead about the money that they are going to get in Iraq. This part functions as a tool showing this fact: That these soldiers ignore the glories and history of their ancestors and give 
importance to money, which may emphasise the capitalist priority of Western imperialism and that the Black Watch soldiers will form a part of this capitalist and imperial ideology.

As a matter of fact, the U.S.A. seeing Iraq as an instrument for its capitalist means has caused much damage not only to Iraq, but also for those who took active roles in the war, such as the Scottish Black Watch regiment. The war, which started with a glorious phantom, actually, resulted in disappointment. Babylon, as a consequence of the Iraq War, means many things at the same time to this regiment. It at first, signifies being a part of Western imperial ideologies that are mythologised and glorified by the U.S.A. and the U.K., then it becomes the symbol of betrayal as the Scottish regiment is sent to the most dangerous combat zone at Camp Dogwood known as "The Triangle of Death" (Burke 2010, 8) at the request of the U.S.A. Gregory Burke, in The Black Watch, presents the story of how the Black Watch Regiment was deployed in this strategic location through real conversations taken from the Today programme. About the deployment of the Regiment in Iraq, Alex Salmond, who was then the leader of the Scottish National Party, stated in the newspaper Today: "These are professional soldiers, they'll do their job, regardless of the danger, they're among the finest infantry soldiers in the world, but we and I believe that this deployment was political in its nature, we think the request was political, the answer was political, during the American presidential election," and he adds: "The Black Watch have been sent in to do an impossible job - eight hundred Scottish soldiers are replacing four thousand American marines and we're actually expected to believe that one hundred and thirty thousand American soldiers in Iraq couldn't do that job" (Burke 2010, 8-9). This was denied by Geoff Hoon, a British politician, who argued that "there was simply no political motive underlying this request from the United States, that this was a straightforward military request, along military lines of communication to satisfy a specific military task" (Burke 2010, 9). The reason for the British Government's sending so many soldiers including the Scottish Black Watch soldiers to Iraq is reflected as only a little "military request." In fact, it was more than this. The Black Watch soldiers, in Camp Dogwood, had to fight in intense close quarter combat. John Humphrys, the presenter of the Today programme, explained this situation in bitter words, which are also restated in this play: "There was deep concern, anger indeed, when the news leaked out a few weeks ago that the soldiers of the Black Watch were to be sent north to help out the Americans in Iraq. The area in which they were to be deployed was described here as the 'triangle of death.' So it has turned out for three of them blown up yesterday by a suicide car-bomber. Eight more were injured" (Burke 2010, 8). Moreover, an officer in his letter says, "I hope the government knows what it has got us into. I am not sure they fully understand the risks" (Burke 2010, 12). Despite all the opposition in the British Parliament, the Black Watch was sent into that dangerous region. Thus, the regiment that acted on behalf of the English imperial ideologies for centuries had, in a way, been betrayed and used by the English administration for their own benefits. As Vicky Featherstone notes, "Greg felt that the Black Watch regiment was an example of Scottish history in relation to English history, in terms of all the [...] imperialist attacks that Britain has undertaken, and the irony of using Scottish Highland warriors to do that. And at the final moment you leave them in the biggest foreign policy disaster ever" (as cited in Pattie 2011, 33). Furthermore, as Pattie emphasises, "[a]t the time that Burke was researching the play, it was announced that the Black Watch was to be absorbed into a new, amalgamated Scottish regiment; for the soldiers currently serving in Iraq, this meant that a crucial part of their communal identity (described in the play as the 'Golden Thread,' binding the current regiment to its history) would disappear" $(2011,33)$. As a result of the war, many Black Watch soldiers experienced trauma and begin to question their historical heroism and national identities which they have always been taught to be proud of. In this 
respect, the Iraq War might also stand for the embodiment of a damaged national myth.

In fact what makes this war remarkably different from Scotland's previous wars in Scottish history in which the Scottish Black Watch played an active role in matters related to imperialism is that in this war, they were not the equal partner of England, but were used by the U.K. Parliament as an instrument to fight in the most dangerous area. This made the regiment question their role in Iraq, and leads them into questioning what they have been doing to the Iraqis. Cammy, too, confesses at the beginning of the play that what they were doing in Babylon was nothing more than "bullying." He says, "people's minds are made up about the war that's on the now ay? [...]. They are. It's no right. It's illegal. We're just big bullies. [...]. Well, we'll need to get $f^{* * * i n g}$ used tay it. Bullying's the $f^{* * *}$ ing job. That's what you have a $f^{* * * i n g ~ a r m y ~}$ for" (Burke 2010,4). They feel a kind of regret as they attended this war, and, as admitted by the officer in The Black Watch, the prestige, heroic identity and honour of the regiment have been damaged due the course of the war. He reflects his views on this: "It takes three hundred years to build an army that's admired and respected around the world. But it only takes three years pissing about in the desert in the biggest western foreign policy disaster ever to $f^{* * *}$ it up completely" (Burke 2010,71). The Black Watch soldiers fought in a country which did not even give harm to them.

By means of The Black Watch soldiers, Gregory Burke uses theatre as a site for criticism of the contemporary imperial ideologies. The play reflects the transition of chaos caused by the violence of never-ending imperial desires from the $20^{\text {th }}$ century into the contemporary world. Cammy, as Burke's spokesperson, says: "This is pish. Sitting about daying camp security. Getting mortared all the time. Getting $f^{* * * i n g ~ a m b u s h e d . ~ G e t t i n g ~ k i l l e d ~ b y ~ s u i c i d e-b o m b e r s . ~}$ And for what? [...]. My mind's made up" (Burke 2010, 70). Only after they go to fight in Iraq do the Black Watch soldiers understand the damage inflicted upon them, the futility and the ugly face of the Iraq War, that they were not fighting for their own country, but were a part of some imperial project, and that the war was fought for oil. When Cammy realises this, he leaves the army saying to the nameless Officer, "I'm going, sir. This could be my last chance. [...] I've fought my war" (Burke 2010, 69), because "he suddenly feels more like an invader of someone else's country than a defender of his own" (Spencer 2008). He asks the most crucial question to the Officer:

Cammy: Well... you ken, I thought I kent why I was here. I really could nay ever have seen myself behind the deli counter in Tesco or anything like that. I always wanted tay be a soldier. And this is way all due respect, sir... [...]. What the $f^{* * *}$ are you doing here?

Officer: What am I doing here? [...]. Well, I'm... I'm... what's the word... [...]. Cursed. [...]. You see... my father, he was in Korea. Nineteen years old, Second Lieutenant. Got wounded. And promoted. And his father, he was at Loos. And his father, well he was more of a gambler than anything else, but you get my drift. [...]. Some of us... It's in the blood. [...]. It's part of who we are, where we come from. It's the reason you join up in the first place. The Golden Thread. [...].

Cammy: Don't you think it's knackered, sir?

Officer: It takes three hundred years to build an army that's admired and respected around the world. But it only takes three years pissing about in the desert in the biggest western foreign policy disaster ever to $f^{* * *}$ it up completely. [...]. But you didn't hear that from me. [...]. We would be off to Afghanistan next. It's going to be exactly the same. 
Kandahar. Helmand province. It's the only place on the planet that might be slightly more dangerous than here.

The noise of an explosion.

Officer: We're going to be hearing that noise for years to come.

Cammy: Not me, sir (Burke 2010, 70-71).

Cammy further explains his ideas to the trench journalists as follows: "When the Reporter asks him, "How have you found life here in Camp Dogwood? There's been a lot of controversy at home about the deployment" (Burke 2010, 38), Cammy says: "It's a buzz, you're in a war ay, but you're no really doing the job you're trained for but it's no like they're a massive threat tay you or tay your country, you're no defending your country, we're invading their country and $f^{* * * i n g ~ t h e i r ~ d a y ~ u p " ~(B u r k e ~ 2010, ~ 38) . ~ I n ~ " P u b ~ 3 " ~ s c e n e, ~ C a m m y ~ r e p e a t s ~ t h e ~ s a m e ~ s e n t e n c e s, ~}$ which reminds one of an echo. This repetition is used as a satiric device to emphasise the idea of "bullying" behind the Iraq War. Moreover, the media here is a tool for reflecting the disturbed psychology of the soldiers. The Black Watch soldiers come to the conclusion after the war that they should not have been here, in Babylon, and, in the end, they do not "want tay be in the army any more" (Burke 2010, 7).

\section{Conclusion}

An in-depth analysis of The Black Watch shows that Gregory Burke, as a Western person, is not a propagandist of imperialist ideologies. On the contrary, he seems highly critical of and disappointed in the consequences of these ideologies. The Iraq War is nothing more than a loss for not only the Iraqis but also for the countries involved in the war, particularly for the U.S.A., the U.K., and Scotland, whose Black Watch Regiment was deployed there by the UK government, because, this war has become a token of the loss of humanity, as many civilians died for only materialist gain. This war might also be considered a signifier of chaos and anarchy for Iraq, which is still continuing in the contemporary world. Babylon as a location, in this sense, represents the new language of communication in contemporary world: violence. This "Ancient home ay Babylon" (Burke 2010, 10) is not only literally but also metaphorically transformed into, in Fraz's words, a "Burnt island" (Burke 2010, 39) through explosions, murders, deaths, fragmentation and chaos in the region. Most significant of all is that the war itself represents a "black" time or black spot in history not only for the Scottish Black Watch, but also for the U.K. and the U.S.A. In relation to these discussions, The Black Watch might be regarded as a satirical representation of this black spot of recent history, and the trauma that the Black Watch soldiers experienced through their participation in this war might be a metaphor for the tragedy experienced throughout the course of this war. 


\section{REFERENCES}

Anderson S. (2014). “The True Story of Lawrence of Arabia”. Smithsonian Magazine (2014).

Source: http://www.smithsonianmag.com/history/true-story-lawrence-arabia- 180951857/?all

Burke G. (2010). The National Theatre of Scotland's Black Watch. New York 2010.

Cantalucci T. (2011). "Iraq: Invasion Ends - Neo-Colonial Rule Begins". Land Destroyer Report (2011). Source: http://landdestroyer.blogspot.com.tr/2011/12/iraq-invasion-ends-neo-colonial-rule.html

Cottle S. (2006). Mediatized conflict: Developments in Media and Conflict Studies. Maidenhead 2006.

Davidson N. (2000). The Origins of Scottish Nationhood. London 2000.

Faulkner N. (2016). Lawrence of Arabia's War: The Arabs, the British and the Remaking of the Middle East in WWI. New Haven 2016. Source: https://books.google.com.tr/books?id=y64ODAAAQBAJ\& $\mathrm{pg}=\mathrm{PT} 669 \& \mathrm{dq}=\mathrm{lawrence}+\mathrm{of}+$ Arabia$\% 27 \mathrm{~s}+$ war\&hl=tr\&sa $=$ X\&redir_esc $=\mathrm{y} \# \mathrm{v}=$ onepage $\& \mathrm{q}=$ lawrence $\% 20 \mathrm{of} \% 20$ Arabia's\% 20 war\&f $=$ false

Foster J. B., Yates M. D., Magdoff H. \& Sweezy P. M. (2002). "U.S. Imperial Ambitions and Iraq". Monthly Review: An Independent Socialist Magazine 54/7 (2002).

Source: http://monthlyreview.org/2002/12/01/u-s- imperial-ambitions-and-iraq/

Greenslade R. (2003). "Their Master's Voice". BBC News (2003).

Source: http://www.theguardian.com/media/2003/feb/17/mondaymediasection.iraq

Hammond P. (2007). Media, War and Postmodernity. London \& New York 2007.

Harvey D. (2003). The New Imperialism. Oxford 2003.

Hoskins A. \& O'Loughlin B. (2010). War and Media: The Emergence of Diffused War. Cambridge \& Malden 2010.

"Iraq Study Estimates War-Related Deaths at 461,000". (16 October 2013). BBC News (2013).

Source: http://www.bbc.com/news/world-middle-east-24547256

"Iraqi Civilians". (2015). Source: http://watson.brown.edu/costsofwar/costs/human/civilians/iraqi

Iyengar S. \& McGrady H. Media Politics: A Citizen's Guide. New York \& London 2007.

Krieger J. (2013). "After Empire". Eds. M. Flinders, A. Gamble, C. Hay \& M. Kenny. The Oxford Handbook of British Politics (2013) 590-605. Oxford.

Loomba A. (2000). Colonialism/ Postcolonialism. London \& New York 2000.

McLeod J. (2012). Beginning Postcolonialism. Manchester 2012.

Oates S. (2008). Introduction to Media and Politics. Los Angeles 2008.

Pattie D. (2011). “Gregory Burke". Eds. M. Middeke, P. P. Schnierer \& A. Sierz. The Methuen Drama Guide to Contemporary British Playwrights (2011) 22-41. London.

Pittock M. G. H. The Invention of Scotland: The Stuart Myth and the Scottish Identity, 1638 to the Present. London \& New York 1991.

Robinson R. (2012). "The National Theatre of Scotland's Black Watch". Contemporary Theatre Review 22/3 (2012) 392-99.

Said E. (1979). Orientalism. New York 1979.

Spencer C. (2008). "Black Watch: Searing Insights into the Horrors of Modern Warfare". The Telegraph (2008). Source: www.telegraph.co.uk/culture/theatre/drama/3555126/Black-Watch-searing-insightsinto-the-horrors-of-modern-warfare.html

Strath B. (2000). "Myth, Memory and History in the Construction of Community". Ed. B. Strath. Myth and Memory in the Construction of Community: Historical Patterns in Europe and Beyond (2000) 19-46. Bruxelles 2000.

Zerdy J. (2013). "Fashioning a Scottish Operative: Black Watch and Banal Theatrical Nationalism on Tour in the US". Theatre Research International 38/3 (2013) 181-95. 